\title{
The Role of Electoral, Administration, and Conflict Resolution in Africa: Comparative Study
}

\author{
Joseph Kwaku Asamoah \\ Director of Training Centre at the Electoral Commission of Ghana, and Facilitator at the Kofi Annan \\ Peacekeeping and Training Centre in Ghana. P O Box GP 19385, Accra. Ghana
}

\begin{abstract}
Elections remain the basic fundamental to any democracy; they are also the political activities most open to manipulation leading to violence in Africa. Whilst in some advanced countries, elections are seen as an instrument for peace, elections in Sub-Sahara Africa are often fraught with conflict and political violence. The role of electoral administrators is very critical in ensuring the achievement of better democracy through elections. Studies indicate that electoral administration is given little consideration in the investigation of political democratisation, especially in transitional democracies. This paper seeks to test whether electoral administration contributes or reduces conflict in Africa through a comparative study between Ghana and Kenya. The study adopted descriptive correlational survey to find out the extent of association between electoral governance and conflicts in Africa. The study stipulated two research objectives and hypotheses. These hypotheses were tested to ascertain their impact on the rate of electoral violence. The results from the study indicated that all two stated hypotheses were supported by the data. The findings show a critical association between the role of election management bodies, electoral system and the rate of violence. The study also discovered high effectiveness of electoral governance in Ghana compared to Kenya.
\end{abstract}

Keywords: electoral administration, electoral conflict, political violence, ethnicity, democratic process.

DOI: $10.7176 / \mathrm{JAAS} / 58-06$

Publication date:September $30^{\text {th }} 2019$

\subsection{Introduction}

The global democratic call for citizens' participation and representation in the affairs of the state, gave some African countries the experience of organising acceptable elections as a means of adopting democratic system. While democratic system of governance goes beyond only elections, it must be noted that real competitive electoral process is pivotal in almost all definitions of democracy (Schumpeter, 1942; Dahl, 1989; Alvarez et al., 2000). However, elections are political events most open to manipulation (Reynolds, 2005). Adam Przeworski succinctly states that "competitive elections are the quintessential manifestation of organized uncertainty in a democracy" (Przeworski, 1991, p.14). In some advanced countries, elections are seen as an instrument for peace, but elections in Sub-Sahara Africa are often fraught with conflict and political violence. The electoral process in Africa's new democracy has with couple of exemptions portrayed by savagery (Omotola, 2008).

Nambiema (2012) avers that, the democratic history of Africa has indicated that competitive elections are double-edged swords which either comes with change of power or social disorganisation leading to conflict and civil unrest. Bekoe (2010) asserts that about $25 \%$ of general elections in Africa degenerates into electoral violence. According to Pastor (1999), local and international election observers have asserted that $41 \%$ of elections in Africa are mostly flawed, while $28 \%$ represent elections with disputed outcome. This puts the democratisation process of many Africa countries on the line, thereby threatening the prospect of democratic stability and consolidation on the continent. For example, approximately 600 people were reported dead and 700,000 others displaced during the 2007 elections in Kenya, which led to violence, following dispute over the election results (BBC News, 2008). Many elections in some African states like Nigeria, Uganda, Zimbabwe, Ethiopia, Chad, and Zimbabwe have produced violence. However, in some countries like Ghana, South Africa, Zambia and Senegal, successful elections have been used to expand the frontier of democracy.

From conflict management perspective, not only should the voting public be allowed to vote regardless of ethnicity, gender, race, class and religion, they should be certain that their vote will count towards deciding the winner. This clearly underscores the crucial role election administrators play throughout the electoral cycle and the impossibility of building a vote-based system with an impromptu methodology. This study adopts a comparative case approach to assess the status of election administration as a conflict resolution mechanism using Ghana and Kenya. The study seeks to identify which of the two countries, competitive elections is quintessential indication of political instability since coincidentally both countries had their 2012 general elections results disputed and contested at their respective Supreme Court with a common ruling, dismissing the claims of the petitioners that, the elections were fraught with fraud and irregularities. The overall objective of this exploratory study is the role of election administration on election-related conflict in Africa. The study adopts a descriptive correlational survey method to establish the relationship between electoral administration and conflict in Africa. The study also focuses on assessing the capacities of the EMBs in Ghana and Kenya in 
conducting free and fair elections with the objective of identifying how their operations contribute to either eliminating or heightening electoral disputes.

\subsection{Research Problem}

There is abundance of literature on election administration in both developed and developing economies around the globe. Studies show that democracy takes place in the shadows of threat of violence in Africa (Acemoglu and Robinson 2006). Studies by Bekoe (2010) indicate that electoral violence affects about $25 \%$ of all general elections in Africa. This has been corroborated by Pastor (1999) that the highest number of election disagreements recorded in Africa is based on disputed electoral outcome. Mozaffar and Andreas Schedler (2002) avers that disagreements and disputes over election results in developed democracies normally fall within the accepted standard "margin of error," but in some African countries election results are flawed due to manipulations and fraud. The role of election administration on violence, dispute and conflict in Africa has been discussed largely by many authors (Chazan, 1982; Nugent, 2001; Friday, 2007; Berman, Eyoh, \& Kymlicka, 2004; Ekeh, 2004). Nonetheless acknowledging the role of election administration in resolving violence, disputes and conflict in Africa still remains unresolved. The reasons why ballots create occasions for bullets in some African countries before, during and after elections, when scholars have so strongly suggested that democracy promotes peace still remain unanswered in literature.

According to Mozaffar (2002), these disputes over electoral outcomes increase tension and eventually degenerate into full scale conflicts. Notwithstanding this danger, Dunning (2011) posits that elections remain an indispensable ingredient in democratic consolidation. Mansfield \& Snyder (2007) theorise that institutional framework must exist for a country to avoid or reduce the threat of violence during transition to democracy. This means that lack or weak institutional architecture needed to manage fragile democracies renders the entire democratic process vulnerable. As this debate wages on, little is investigated about the impact of election administration, particularly the performance of election management bodies on conflict resolution in emerging democracies. A study by Lund (2003) indicates that 68 election-related deaths have occurred in Ghana since the reintroduction of multiparty democracy in 1992. In Kenya, by contrast, elections have degenerated into violence, and ethnic conflict. Studies show that between 1991 and 1997, election-related clashes led to about 1,800 deaths, 3,000 injured and 600,000 individuals displaced in Kenya (KHRC, 2011). Not only was the 2007 fraudulent election a setback to democracy, post-election violence killed about 1,500 people and displaced 700,000 others (USIP, 2010). The value of damage to property in election-related clashes in Kenya was estimated to be KES 210 million (USD 2,625,000) (Africa Watch, 1993, 42). Again, violence surrounding Kenya's 2007 elections resulted to 117,216 individual assets damaged, while 491 state properties were damaged as well (CIPEV, 2008, p. 346).

The question is why has Kenya's elections collapsed into fraud and widespread violence, and why has Ghana's elections remained peaceful and facilitated its democratic consolidation? Elections in Ghana have remained relatively free of malfeasance and violence. This comparative study is particularly important because both Ghana and Kenya have had high levels of support for democracy, previous peaceful democratic transfers of power, significant ethnic diversity, and similar levels of economic development. The general goal of this study is to understand the role of electoral administration in democratic governance and whether it contributes in any significant way to reducing or heightening conflict in Africa through a comparative study. The study adopted a descriptive correlational survey to measure the relationship between electoral administration and conflict in Africa.

\subsection{Significance of Research}

The misleading but high tendency to equate elections to democratic credential of a country underscores the main essence of this study. The decision to select Kenya and Ghana makes the study expedient. Ghana's GDP currently stands at USD65.5 billion with a population of about 30.28 million and annual growth rate of $6.7 \%$ (GSS Report, 2019). Comparative to Ghana, Kenya's GDP stands at USD78.5 billion with a population of 48.5 million and annual economic growth rate of $4.9 \%$ (KNBS, 2019). Although Kenya has a higher GDP than Ghana, economic indicators show that Ghana has a high GDP per capita of \$2,214 than that of Kenya's \$1,681. Again, the annual economic growth of Ghana's $6.7 \%$ is higher than that of Kenya's $4.9 \%$. The two countries have been rated differently in terms of electoral politics despite their historical convergence according to Afro Barometer Report (2006). Ghana is the first country in the Sub-Sahara Africa to gain independence in 1957. Kenya attained independence status in 1963. Ghana is rated high above Kenya in comparative African ranking (Afro Barometer, 2006). For example, whilst Kenya's 2007 presidential election produced widespread fraud and violence, which was, described as a clear setback to democracy, that of Ghana's 2008 presidential elections remained peaceful and facilitated its democratic consolidation. However, coincidental it was in 2012, both countries had to settle the dispute over the outcomes of their 2012 presidential elections result at their respective Supreme Court. The study is therefore significant for accounting for the differences in the processes of electoral management, 
administration and conflict resolution in Ghana and Kenya. This study would provide comparative insights in electoral administration and conflict resolution mechanism for countries in Africa and beyond.

\subsection{Research Questions and Hypothesis}

Many Africa countries have had their presidential elections degenerating into violence and conflict. The stability and security systems of African countries hinges on disequilibrium during periods of elections as results of threat of electoral related violence across the sub region. As a result of the increasing election brutality in Africa, this study is anchored on the following questions:

1. What is the relationship between the performance, independence, credibility of election management body and the rate of electoral violence in Africa?

2. Is there is a relationship between electoral system and electoral violence in Africa?

\section{0 Theoretical Orientation for the study}

Elections take place on the basis of certain accepted theoretical, legal and empirical framework. The concept of democracy remains a puzzle despite countless attempts by academics and practitioners to find a common ground. This paradox continues to be one of the key contending issues among many scholars, researchers and authors in the field of political science, political economy and other related field. It must be noted that, different definitions and theories emphasise different aspects of democracy. Lindberg (2006) recognizes that there is no necessary link among a particular term, like democracy, the conceptual construct in the mind, and the empirical phenomenon to which it refers.

Various studies have shown a strong relationship between elections and democracy. In disputing electiondemocracy theory, some scholars argue that although democratic processes could be reduced to the holding of internationally observed multi-party elections, there still remain no agreement on the definition and principles of democracy (Ake 1996; Colomer, 2000 et al.). Whilst these studies see democracy as bigger than elections, others restrict the definition of democracy to elections. Bratton and van de Walle (1997) posit that while elections can take place without democracy, democracy cannot take place without elections. Some scholars have, in the Schumpeterian way reduced democracy to elections (Dahl, 1998; Huntington, 1991; Schumpeter, 1942; Karl, 1990; Alvarez et al., 2000). According to these scholars, democracy is best defined in terms of competitive electoral politics and the institutional structures that come with it. Agbaje and Adejumobi in their effort to investigate the central role of elections to democracy averred that 'election is a suitable system for culminating delegate government' (Agbaje and Adejumobi, 2006, p.26). In supporting the centrality of elections to democratic governance, Lewis (2007) contends that elections serve as an affirmation of democratic rights, inclusion, and transparency. According to Jinadu (1997), election is an inclusive and participatory tool for citizens integration in the democratic affairs of a state. While elections do not, all by themselves, constitute an all-round democracy, Bratton (1998) avers that they, nonetheless, remain essential for rule by majority system and also a fundamental imperative, for more extensive democratic consolidation. This means that elections have become an indispensable and unavoidable requirement and necessity of democracy.

Competitive elections play a central role in democracy (Dahl 1998; Karl 1990; Alvarez et all., 1996). Cohen (1983) contends that the primary value of elections is to educate, entertain and give the citizens a feeling of participation in the affairs of governance. Citizens influence on government policies, according to Van Ham (2009), is defined as how government is responsive to the policy preferences of voters. Thus, asking to what degree governments formed after elections implement policies that are congruent with the policy preferences of voters. The outcome is that, elections allow the people to participate in choosing representatives and by extension, in the formation of governments in a competitive manner. This means that elections afford people the opportunity to choose who they want to lead them (Thomassen, 1994). Moreover, elections have also been seen as an essential instrument for economic development. Feng (1997) argues that political competition enhances democratic governance thereby promoting economic growth. In an attempt to show the relationship between elections and development, Kambudzi posits that 'properly conducted elections in any African nation would be a noteworthy commitment to Africa social and material development' (Kambudzi, 2008, p.1). According to Kambudzi, elections enhances the lives of natives by offering them perspectives and alternatives by political contestants on fundamental issues of national life and settling on weighted decisions among them.

Scholars of democratisation have begun to ask whether elections might have spill-over effects on other components of the political regime, thereby triggering broader democratic processes (Lindberg, 2006; 2009). The quality of the electoral process is then likely to be a crucial factor, as engaging in electoral manipulation and fraud might be an effective strategy for governments that seek to avoid being held accountable for their past actions, and an incumbent that came to power through fraudulent elections might have little incentive to be responsive to citizens' needs (Van Ham, 2009).

Various evaluation criteria and datasets have been employed by many scholars in assessing the quality of democratic elections (Pastor, 1999; Van de Walle, 2003; Elklit and Reynolds, 2005a; Lindberg, 2006a; Birch, 
2008, 2011; Hartlyn et al., 2008). However, investigating the nexus between elections and democracy go beyond academia, as the international community sees investment in democratic governance in developing countries crucial for global peace. For example, the United Nations Development Program (UNDP) dedicated about $35 \%$ of its annual budget in 2009 to democratic governance, representing USD1.4 billion, a substantial part of which was dedicated to electoral assistance.

The question as to whether high quality elections have consequences for democracy as expressed in the absence of popular protests, civil war or coup d'états continues to generate interest among academics and policy makers. A number of different conceptualizations have emerged on quality of elections (Elklit and Svensson, 1997; Pastor, 1999; Schedler, 2002a; Mozaffar and Schedler, 2002; Elklit and Reynolds, 2005a; Lindberg, 2006a; Birch, 2008, 2011; Lopez-Pintor, 2010). The quality of an election can be conceptualized as the degree to which political actors at all levels and from different political strands see the electoral process as legitimate and binding. However, scholars have expressed divergent opinions about election quality either positively, by specifying the presence of criteria that render elections democratic, or negatively, by identifying the principle-violations that cause elections to be undemocratic. Positive definitions use conceptual labels ranging from free and fair elections, clean elections and democratic elections (Elklit and Svensson, 1997; Lindberg 2006a; Munck 2009; O'Donnell, 2001). Negative definitions on the other hand, refer to flawed elections, electoral malpractice, electoral manipulation, electoral fraud and election rigging (Pastor 1999; Birch, 2008; Schedler 2002a; LopezPintor, 2010).

Elklit and Reynolds (2005a) for example, identify the following 11 sequential steps in the electoral process that define election quality-legal framework, electoral management, constituency and polling demarcation, voter education, voter registration, access to and design of ballot paper, party and candidate nomination \& registration, campaign regulation, polling, counting and tabulating the vote, resolving election related complaints, and postelection procedures. Mozaffar and Schedler (2002) distinguish the 3 phases of quality election administration: rule-making defines the ex-ante choice of rules of electoral competition and rules of electoral governance, rule application which deals with organizing the electoral contest, and rule-adjudication that deals with effective handling of ex post publication of election results and resolving disputes.

\section{1 Election Management Bodies (EMBs) and Electoral Violence.}

Electoral governance must exist within the framework of institutional architecture. Zafiu (2012) posit that the choice to analyse development of institutions is a significant condition for the success or failure of post-war elections. According to Zafiu, the efficiency of policy implementation by these institutions can shape expectations, build confidence or ignite fear among state actors. The most eminent institutional architecture with the end goal of this study is the election management bodies (EMBs). Domestic and international actors consider EMBs an important framework for democracy because of its strategic role in shaping the quality of elections and democratisation. This makes the review of the theoretical framework that exists between EMBs performance and electoral violence imperative in this study. According to Kerr (2013), EMBs matter for elites in emerging democracies because their performance directly influences the likelihood of electoral manipulation and the incidence of electoral administrative irregularities. In distinguishing the two dimensions of EMB performance: autonomy and capacity, Kerr argues that variations in EMB autonomy and capacity shape the strategic interaction of elites as well as their evaluations of electoral integrity. EMB must ensure that the electoral process is transparent enough to give free, fair and credible electoral outcome.

A study by Sue (2001) on electoral process from the perspective of an electoral management body, divides the process into four main steps: establishment of the EMB and legal framework; EMB planning; EMB implementation; and EMB post-election review and revisions. Reynolds (1999) attests that the readiness and arranging stages of election administration are regularly neglected in light of the tight timelines within which EMB's conduct elections. A well-planned and well-organized election that is professionally and precisely regulated can expand cooperation by competitors and voters, and construct confidence in the electoral process and the election results (Harris, 1998). This implies that good arrangement can maintain a strategic distance from a considerable lot of the issues that Reynolds (1999) portrays as obstacles to electoral administration.

Election administration can be affected by many factors. These factors according to Sue (2001) include: experience level of EMB; quality of the legal framework; level of trust and degree of consensus on the electoral system and EMB; availability of time and resources; political and cultural history; and degree of participation and quality of partnerships. In addition to this, Nyamu (2003) enumerate some general factors that affect the quality of EMB to include: the organizational level of the EMB, the quality of its systems, planning, personnel, procedures, training, budget and oversight; degree and quality of EMB consultations with political parties/candidates; the EMBs level of accessibility and its openness to correct problems found during implementation; degree of dissemination of voter education information to public; degree of enforcement of election law and code of conduct; and the degree of trust built up with the public, political actors and government. 
EMBs as part of ensuring the legitimacy of the electoral process are required to enforce the rules of the game and assure fairness with the cooperation of political parties and citizens. This according to Lopez-Pintor (2000) requires EMBs to be inclusive, sustainable, just and independent. Various studies have attributed the causes of election-related disputes, violence and conflicts in Africa to the weaknesses in electoral systems, electoral administration and dispute resolution mechanism (Gurr, 1993; Pastor, 1999; Reynolds, 2005). According to these studies, in order to reduce the rate of electoral violence in transitional democracies there must be the need to have an effective electoral system. Huntington (1991) corroborates this assertion by stating that the gap between high levels of political participation and poorly integrated institutions is one of the key problems of political development in transitional democracies. Election Management Bodies (EMBs) are responsible of the administration of the election. According to Kerr (2013), the design of EMBs relates to the rules of electoral administration, and that EMBs are the institutions responsible for making sure that these rules are being implemented effectively and impartially during the election period. Powell (2004) regards EMBs as "instruments of democracy". This is particularly important in emerging democracies where there is less confidence in the legitimacy of other political and state institutions not to manage elections in favour of the incumbent. EMBs help ensure "procedural legitimacy" and "substantive uncertainty" of elections by effectively managing various aspects of the electoral process and holding political elites accountable to the rules of the electoral game (Mozaffar and Schedler, 2002).

Studies and policy orientation indicate that election management bodies can be distinguished as independent, governmental, and mixed models (Hounkpe et all., 2011; López-Pintor, 2000; Wall et al., 2006). According to López-Pintor (2000), three categories of EMBs exist in Africa's new democracies. López-Pintor points out that $53 \%, 8 \%$ and $39 \%$ of EMBs in Africa constitute the independent, government, and mixed models respectively. It must be noted that the degree of independence of an election management body affects the level of confidence in electoral process. According to Elklit \& Reynolds (2001), public perception about the independence of EMB is almost as actual as the outcome of elections. Lehoucq and Molina (2002) goes further to aver that independence of EMBs is a cardinal institutional development that strengthens the democratisation process in some countries. Studies also show that EMBs associated with the government may reduce the perceived institutional independence, and hence, confidence in the election outcomes (Elkit and Reynolds 2002; Hartlyn et al. 2008). In supporting this position, Wall et al. (2006) assert that elections conducted by EMBs that are accountable to government and financed with ministerial budgetary allocation lack credibility in the face of voters. This suggests that EMBs with excessive governmental influence may lead to a perceived lack of professionalism and impartiality that lead citizens to question the fairness of the election process (Shane, 2009). Höglund, Jarstad and Söderberg Kovacs (2009) corroborate this contention by concluding that government-based electoral management bodies are more prone to political manipulation with tendencies of creating electoral violence.

While the functions and responsibilities of EMBs vary across countries, some of the core functions and responsibility include registering voters and candidates, training electoral staff; conducting elections, tabulation and counting of votes, and, announcing election results. A more fundamental issue relates to the question of professional and impartial application of dispute resolution laws by the EMBs. According to Asamoah (2019), to prevent electoral violence in Africa, the core assignment of the election management bodies is to conduct elections with integrity, credibility and free and fair in order to guarantee the acceptability of the election results to prevent the electoral body from accusation of fraud. However, it is unclear whether EMBs would be considered independent given that they are also a stakeholder to administer the elections. According to Omotola (2009), while laws are important to shape and reshape electoral contests and provide the basis for litigation in the event of violations, no law can, on its own, guarantee fair play in the conduct of elections. Election management bodies must therefore commit to the principles of independence and impartiality in order to achieve the buy-in by candidates and the general public. This would enable these EMBs to conduct elections that comply with laws to avoid interference of state actors in the discharge of their functions. In order to professionalise itself, the electoral commissions should undertake intensive capacity building trainings to minimise the number of disputes that would arise as a result of electoral administration (Asamoah, 2019). Figure 1 shows EMB models. 


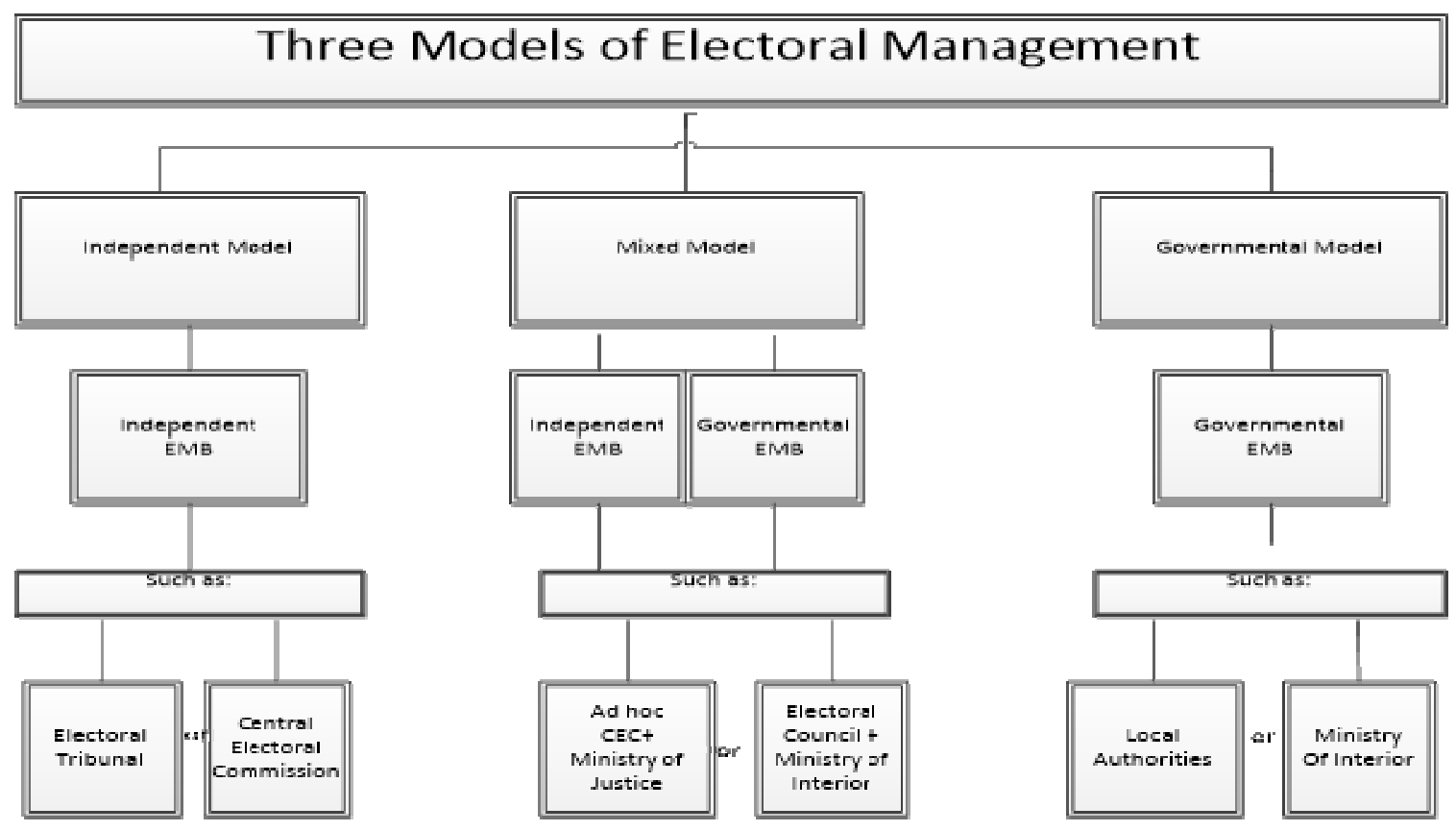

Source III A (200) 5 uryer

Figure 1: The Three Models of Electoral Management

It can be posited that electoral contestants can see electoral process and results as acceptable when the elections meet some established standards such as participation, competition and legitimacy. These democratic indicators can be guaranteed on condition that the EMB provides the framework that strengthens effective electoral administration. Omotola (2008) identified this framework to include the autonomy of the EMBs measured in terms of their structure, motivation, transparency and general capacity. These conditions can be achieved if the EMB is insulated from governmental abuse. This mean that the configuration of EMBs could determine the quality or otherwise of an electoral outcome with its resultant effect on peace and conflict. For example, in Côte d'Ivoire, the Independent Electoral Commission (CEI) always has their election results validated by the constitutional court before a president is deemed to have been validly elected. This election management model created political crisis in Ivory Coast after the 2010 elections when the President of the Constitutional Court, a known supporter of Laurent Gbagbo, Paul Yao N'Dré, invalidated the election results of CEI and declared Laurent Gbagbo as the winner (Bassett 2011). Table 1 shows the distribution of EMB models in Africa. 
Table 1. Distributions of EMB Models in Africa

\begin{tabular}{lll}
\hline Government & Mixed & Independent \\
\hline Togo & Burkina Faso & Angola \\
Cote d'Ivoire & Burundi & Benin \\
Guinea & Cameroon & Botswana \\
Djibouti & Cape Verde & Congo DR \\
Mauritania & Central Africa Republic & Gambia \\
Rwanda & Chad & Ghana \\
Seychelles & Comoros & Guinea Conakry \\
& Republic of Congo & Guinea-Bissau \\
& Equatorial Guinea & Kenya \\
& Gabon & Lesotho \\
& Madagascar & Liberia \\
& Mali & Malawi \\
& Senegal & Mauritius \\
& Togo & Mozambique \\
& & Namibia \\
& & Nigeria \\
& & Niger \\
& & Sierra Leone \\
& & South Africa \\
\hline N $=7 \%)$ & & Tanzania \\
& & Uganda \\
& & Zambia \\
& & Zimbabwe \\
\hline
\end{tabular}

Source: Electoral Management design: International IDEA handbook (2006)

\subsection{Causes of Electoral Conflicts in Africa}

Electoral violence is not restricted to election day alone. It can happen before, during and after the elections. Most African countries have experienced political crisis and democratic setbacks due manipulations in the electoral process. According to Hyde and Marinov (2012), electoral violence has increased by 50 percent in Africa between 1990 to 2006 compared to the period between 1945 and 1989. Fischer (2002) posits that these violence results from an electoral process through threat, verbal intimidation, hate speech, disinformation, physical assault, blackmail, destruction of property, hijacking of electoral materials at gun point, and political assassination. The most glaring appearance of constituent brutality is at some point the notorious open affirmation by contesting candidate that election is 'a do or die business' (Omotola 2007). These pronouncements go far to portray that the elections must be won at all cost. This breeds apprehension in the psyches of the electorate. Studies have related the reasons for election related clashes to variables such as negative impact of ethnicity, religious contrasts, political publicity and exploitation by the political elites. Bekoe (2010) asserts that the risk of electoral violence is likely to be high in Africa due to the formation of political parties along ethnic groupings. Again, research indicates that ethnic cleavages are significantly associated with voting behaviour and structure of party systems in Africa (Horowitz, 1991, 1993; Mozaffar et al., 2003; Norris and Mattes, 2003; Posner, 2005). Political parties in Africa seek to win power through polarisation and exploitation of exiting fault lines among diverse ethnic groups for votes. This increases the rate of antagonism and prepares the ground for violence at the least provocation.

Tensions over land rights, employment and ethnic marginalization are three common sources of recurring electoral violence. Bekoe (2010) concludes that these areas intersect and manipulated by politicians to their advantage. Wilkinson (2004) contends that in a vote-based systems ethnicity is considered as a forceful crusade used by political elite to cement ethnic dominance and decrease the significance of other politically important personalities. A case in point is the ethnic make-up of governmental issues and the state fueled hegemonisation by diverse parties in the Kikuyu ethnic clan during the 1963-1978 Kenyatta administration in Kenya. This "Kikuyuisation" involved combining political power leading to controlling interest in the Kenyan economy (AMANI Forum, 2008, p.11). According to Hornsby and Throup (1992, p. 191), when Moi assumed control in 1978, he embarked on a decade of gradual 'de-Kikuyuisation' and 'Kalenjinisation' of Kenya. Fundamentally, Moi destroyed President Kenyatta's Kikuyu network of the political and economic elite and supplanted it with an effective coterie of his supporters, predominately ethnic Kalenjins (Foeken and Dietz, 2000, p. 124). The ethnopolitical fusion creates situation where political parties are formed on ethnic lines to promote ethnic and 
sectarian ideologies. This supports the assertion that ethnic voting and ethnic parties worsen divisions as opposed to alleviating them.

Conflicts associated with elections have been placed at the door steps of some African leaders and losing political parties for several reasons. A common cause of election violence is the cost of winning and losing political contest in Africa. Collier (2009) opines that, because the stakes of winning and losing are very high, elections may deepen communal frictions. According to Andreas Schedler (2006), elections are tools of manipulation employed by authoritarian governments to hold on to political power. Studies indicate that incumbents' manipulation of the electoral system to hold on to power contribute to election-related violence in Africa (Whitaker, 2005; Bah, 2010; LeVan, 2011). This is manifested when incumbent government manipulate electoral laws to exclude sections of the community which threaten the security of the states. A specific example is where the incumbent government used the concept of Ivoirité-a policy introduced to identify indigenes from non-indigenes of Côte d'Ivoire as a discriminatory political tool to disqualify Alassane Ouattara as a presidential candidate in the 1998 and 2000 elections (LeVan, 2011).

According to Wolf et al., 2004, Kenyans see political issues to be the second most noteworthy cause of conflict after boundary and land disputes. This means that periods of political crusades could create clash and asperity among political party supporters. On the other hand, Saideman \& Lanoue (2005) assert that elections may serve to reduce extreme forms of dissent, as individuals and groups focus their efforts on getting their representatives elected by traversing societal cleavages to canvas for votes. They argue that elections may lead to restraint as groups try to avoid antagonising potential voters and build coalition partners. However, regardless of this assertion, many still believe that some activities of political parties directly or indirectly cause conflict before, during and after elections. These may include fraud, intimidation, gerrymandering, vote rigging and illegal interference with the electoral process.

Again, studies have shown the effects of the closeness of elections results on stability and violence (Chacon, Robinson and Torvik, 2011; Przeworski, 1991; Colomer, 2000, Weingast, 1997). These researchers propose that the situation most favourable to the combination of vote-based system is equitably coordinated party rivalry. Evidence suggests that the credibility of the electoral management body can be a fertile source of electionrelated violence. This means that imperfect elections can fuel potential post-election conflict (Brancati \& Snyder, 2011). Although some countries have been able to immune themselves from election-related violence, evidence from many other countries suggests that election- related violence is widespread (Lindberg, 2009). A study by Fischer (2002) revealed that at least $50 \%$ of electoral processes observed in 2001 manifested significant electionrelated violence before, during, and after the polls. According to Fisher, while no single theory can account for all the root causes of election violence, there is general agreement that three elements are critical: the context of democratization or political change in which violence occurs, the effects of electoral system choice on conflict dynamics, and the nature and patterns of political mobilisation. It is therefore important to scrutinise public views on politics, elections, and security in determining threats to peaceful elections periodically.

\subsection{Election Dispute Resolution Mechanisms (EDRM)}

Literature on electoral studies suggests that democracy can have a dual purpose: promoting representation and institutionalising conflict resolution. Nonetheless, much of Sub-Saharan Africa has experienced conflict in recent decades. Majority of these conflict-related deaths, injuries and destruction of properties are election-related. As indicated by United States Institute for Peace (2010), 19-25\% of elections in sub-Sahara Africa degenerates into violence. In most of these cases, violence recurs because of unresolved systemic issues with the youths at the center as both culprits and victims. Staffan Lindberg (2009) argues that elections can act as a vehicle of democratisation or regime reproduction. Studies by Paul Collier, Mansfield and Jack Snyder demonstrate that there is a high risk of elections in post-conflict situations re-igniting the conflict they are supposed to resolve (Collier, 2009; Mansfield and Snyder, 2007). According to Tohbi (2009), elections have acted as a trigger for violent conflict in many countries in Africa. However, much of these studies tend to focus on the causes rather than solutions to election-related violence. As a result, conflict prevention, management and reduction (CPMR) and peacebuilding among political stakeholders must be prioritised on continent to ensure that zero sum elections do not produce extreme outcomes.

There are various forms of managing election disputes. As indicated by Ifeanyi (2006) there are two noteworthy techniques for resolving conflicts. These are Regular Dispute Resolution and Alternative Dispute Resolution. According to ifeanyi, disputes happening before, during, and after election can be managed utilizing five possible approaches. These are avoidance/denial; strategic withdrawal; confrontation; third party decisionmaking and joint problem solving. The avoidance/denial procedure includes doing nothing about the issue with the trust that, with time, it would go away. The strategic withdrawal technique like the avoidance/denial the intervener does not take any prompt action on the issue or takes a mild decision but grabs the opportunity to buy quality time and space to arrange and take more decisive action. An excellent illustration is the ECOWAS dispute resolution approach in Togo after the demise of President Eyadema in 2006. As Albert (2006) briefly 
puts it when the military attempted to forcefully seize power in Togo in 2006, ECOWAS requested that Togo reverses the situation within a stated time after which some other more punitive action would be taken against the country. This decision of ECOWAS was contrary to the call by the international community for the subregional body to employ military power to accomplish the goal. The Third-party decision-making has to do with having to refer the conflict to a higher body with decision-making powers for settlement. In most cases, this approach involves judicial settlement-a legal mode of end of dispute. An example is the judicial settlement of election petitions or referring a related matter to the ECOWAS Court of Arbitration for settlement. Case in point is when the original jurisdiction of the Supreme Court was invoked in Ghana and Kenya to adjudicate on the 2012 and 2016 election petitions in the respective countries.

The five dispute resolution methods can be further broken into two broad categories: the adversarial and non-adversarial dispute resolution. The adversarial methods are those that depend absolutely on legal framework and the use of legal compulsion. On the other hand, the non-adversarial method, negotiation and mediation are the two most important dispute management mechanisms in the alternative dispute resolution spectrum. This is because negotiation and mediation allow the disputants to determine the outcome of the peace process. It is worthy to note, however, that official bodies mandated to resolve election disputes depends largely on legal framework in the context of a particular country. This makes the situation differ from country to country. However, five methods are extremely unmistakable in surviving writing in the context of electoral administration. The first is for election management body to deal with the dispute over the election results. The second is for the dispute to be dealt with under the regular judicial process where cases could go as far as the country's Supreme Court. The third is for the matter to be taken to a constitutional court or bodies of constitutional justice as reminiscent in some francophone electoral systems and the fourth is for the matter to be dealt with by a special electoral tribunal. Sweeney (2010) observed that regardless of whether election disputes are solved by a constitutional court, an independent tribunal, or an electoral complaints commission, the adjudicative procedure must adherence standards to ensure that specific post-election remedy systems comply with obligations under relevant international and domestic law.

It is therefore important for political parties, contesting candidates, civil societies, election management bodies and the media to subject themselves to grievance procedure framework to help actualise these standards. More specifically in Ghana, individuals dissatisfied with the decisions of the Electoral Commission can go to courts, including cases involving voter registration and candidate nomination. Settlement of challenges to an application to register as a voter is under the responsibility of the District Registration Review Committee and its decision can be appealed to the Chief Registration Officer (High Court Judge of the respective Region). For the purposes of hearing cases relating to a challenged application at the time of registration, a District Registration Review Committee (DRRC) is established by law in each district, made up of representatives of the active political parties in a district and not more than four local persons known to be neutral and fair-minded. The Secretary to the District Registration Review Committee is the District Electoral Officer. The law provides that the District Education Director, and a representative of the traditional authority in the district be members of the committee. The electoral laws further provide that the Supervising High Court Judge of each region should be the Chief Registration Review Officer for the region and should determine appeals from voters aggrieved by the decision of the DRRC. The District Registration Revising Officer who is the Magistrate of the District Court settles objections or complaints related to the provisional voter register and the Magistrate's decision can be appealed to the High Court. The validity of a parliamentary election can be challenged by a petition presented to the High Court within 21 days after the date of publication in the Gazette of the election results. However, if the election petition boarders on grounds of corrupt practice involving payment of money, it may be presented to the High Court before the official publication of results is gazetted (PNDC Law 284).

\subsection{Research Methodology}

This segment of the study describes the appropriateness of the chosen methodology. According to Polit and Hungler (2004), methodology refers to the way of obtaining, organizing and analyzing data. The study was predicated on the ideals of ontological and epistemological assumptions of quantitative research. A correlation descriptive survey approach was used to determine the role of electoral administration on conflict resolution in Africa. The study utilized existing theories and definitions to address the research questions since these questions focused on the level of relationship between the predetermined variables of election administration and conflict resolution (Creswell, 2001). The survey was set out to obtain data on respondent's opinion, experiences and attitudes about the role of electoral governance on conflict in Africa. Judgmental or purposive sampling method was employed to conduct the study. The population comprised persons in Ghana and Kenya. The target population consisted of election administrators (EMBs staff of the two nations), returning Officers (ROs), presiding officers (POs), civil societies, media, political parties, academia, and social movement groups. Data collection was done through administering structured questionnaires to respondents. A response rate of less than ten percent was expected. Due to interest in the study a response rate of $100 \%$ was achieved. A central web- 
based domain was created. The e-mails sent inviting responses included a link, and 'double clicking' this link would take the respondent directly to the web-based survey. A total of 1,200 responses were received with 600 each from the two countries. The difficulty encountered was the seemingly low connectivity of the internet in terms of downloading responses for analysis. The rational of adopting the survey method in this study is the ability to gather data from a large sample of the population as asserted by (Creswell, 2001; Leedy \& Ormrod, 2005).

The resultant statistical indicators from Ghana and Kenya was compared and contrasted to ascertain the general relationship between electoral administration and election-related violence. Demographic and personal profile information on respondents was gathered. This information on gender, marital status, and education on citizens in both countries used descriptive, paired wise test and correlational analysis to determine statistical and comparative figures on the sample population. Descriptive statistical analysis was used to deduce the extent of the relationship between the dependent and independent variables. To ensure construct validity, a correlational coefficient between Ghana and Kenya was expected to average above 0.80. According to Chan and Chow (2005), construct validity with correlational coefficient of 0.898 and a re-test reliability coefficient of 0.803 is an average required to ensure instrument validation.

\subsection{Analysis and Presentation of Results}

An essential component of ensuring data integrity is the accurate and appropriate analysis of research findings. According to Shepard (2002), improper statistical analyses distort scientific findings, mislead casual readers and may negatively influence the public perception of research. This means that integrity issues are just as relevant to analysis of non-statistical data as well. The purpose of this research study is to identify the role of electoral administration on conflict resolution in Africa. This segment of the study shows the demographic characteristics of respondents, and statistical data analysis. It presents descriptive statistics, frequency tables, figures in providing a better view of analysis in line with the stated research hypotheses.

Table 2. Sample Distribution of Respondents on the Number of Electoral Administrators in Ghana and Kenya

\begin{tabular}{|c|c|c|c|c|c|}
\hline \multirow[t]{2}{*}{ Electoral Administration } & \multicolumn{2}{|c|}{ Ghana } & \multicolumn{2}{|c|}{ Kenya } & \multirow[t]{2}{*}{ Total } \\
\hline & Freq. & $\%$ & Freq. & $\%$ & \\
\hline Returning officers & 5 & .83 & 5 & .83 & 10 \\
\hline Presiding officers & 100 & 16.67 & 100 & 16.67 & 200 \\
\hline Civil Societies & 100 & 16.67 & 100 & 16.67 & 200 \\
\hline Mass Media & 150 & 25.00 & 150 & 25.00 & 300 \\
\hline Political Parties-Members & 40 & 6.67 & 40 & 6.67 & 80 \\
\hline Academia & 100 & 16.67 & 100 & 16.67 & 200 \\
\hline Election expect & 55 & 9.16 & 55 & 9.16 & 110 \\
\hline Social Movement Group & 50 & 8.33 & 50 & 8.33 & 100 \\
\hline TOTAL & 600 & 100 & 600 & 100 & 1,200 \\
\hline
\end{tabular}

Table 2 shows the analysis of sample distribution of respondents on the number of electoral administrators or EMBs adopted for the study. The results show that there were eight dimensions of electoral administrators that the study looked at namely; returning officers, presiding officers, civil societies, mass media, political party officers, professionals in academia, election expect/observers and some social movement group in both Ghana and Kenya. The analysis show that out of 1,200 respondents selected for the study with 600 of respondents from Ghana and 600 respondents from Kenya, majority of them were from mass media in both countries representing $25 \%$, followed by those from academia, presiding officers and civil society group representing $16.67 \%$ of each country respectively, followed by election experts or observers representing $9.6 \%$ and the least represented were returning officers from both country representing $0.83 \%$ respectively. Due to limited number of returning officers in Ghana and Kenya, the number was significant for the analysis. 


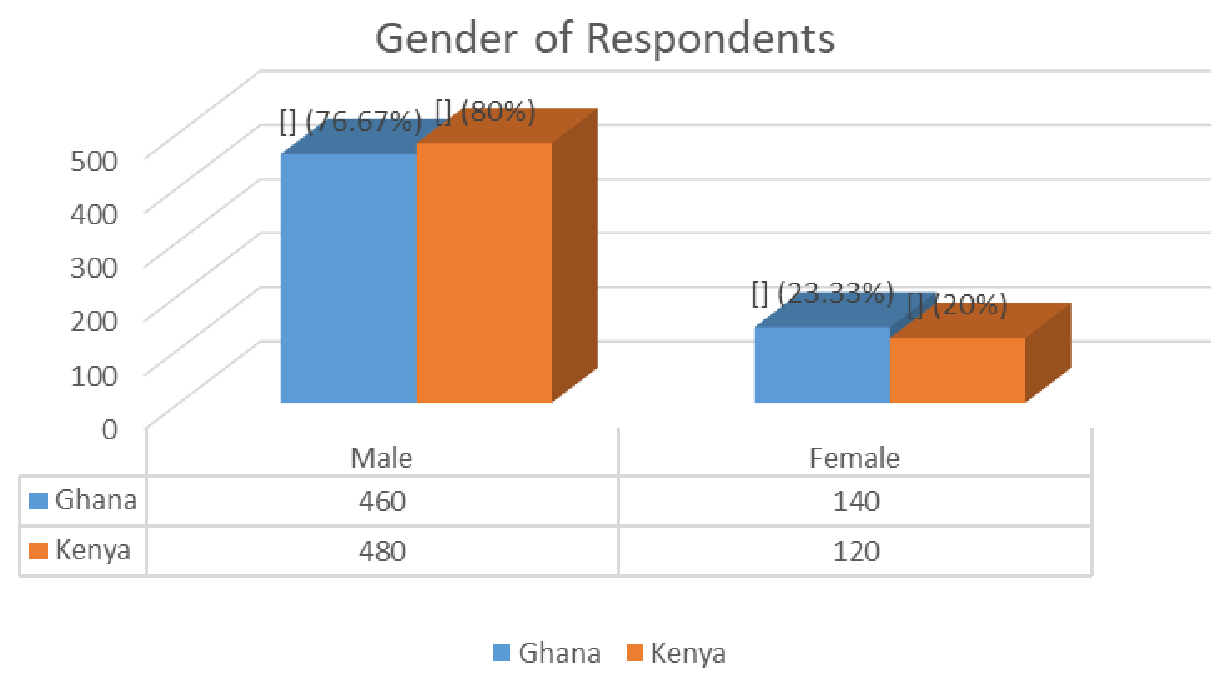

Figure 2: Sample Distribution of Gender Respondents of Election Administrators

Figure 2 shows the analysis on sample distribution of gender of respondents of electoral administrators used for the study. The results show that out of 600 respondents from each country (Ghana and Kenya), in connection with Ghana, majority of them were males with 460 respondents representing $76.67 \%$ whiles the rest were females with 140 respondents representing $23.33 \%$. Comparative to Kenya, majority of respondents were males with 480 representing $80 \%$, while the rest of the respondents were females with 120 respondents representing $20 \%$. Overall, Kenya male respondents were slightly higher than that of Ghana, but female respondents in Ghana observed a slightly higher number than that of Kenya.

The study stipulated two main hypotheses to be tested. The first hypothesis stated that there is a relationship between election management body and the rate of electoral violence in Africa. In order to test this hypothesis, the spearman rank order was employed to test this issue from the views of electoral administrators. In testing this particular hypothesis four main issues were tested namely; performance, credibility, independence and rate of electoral violence. In determining performance, credibility, rate of electoral violence and independence of election management bodies (EMBs) in Ghana and Kenya in light of the relative quality of election is not a simple undertaking. One challenge argued by Mahama (2012), was the basis of determining how EMBs' performance, credibility, independence influences election-related violence in emerging democracies, particularly in multi-ethnic societies in Africa.

According to Mozaffar and Schedler (2002), in the democratisation process in Africa, election, has become a curse to some countries and a blessing for others. The researchers content that elections should be procedurally fair and technically sound and the results should reflect the will of the voters, freely expressed at the ballot box. In turn, the process should enhance public confidence in the electoral system as a whole because of its perceived fairness, accuracy, and efficiency which should invoke the acceptance of the results by all as credible. But as discussed in the previous chapters, elections conducted in some emerging democracies have either precipitated political disputes or have escalated simmering tensions to an outburst of conflict. In order to establish the relationship between EMB's and the rate of electoral violence various questions were asked to ascertain this relationship by the use of spearman rank order correlation. Table 3 shows the assessment of the relationship between Election Management Body and the rate of electoral violence. 
Table 3. Analysis on assessing the relationship between Election Management Body and the rate of electoral violence.

\begin{tabular}{|c|c|c|c|}
\hline EMB & \multirow{2}{*}{ 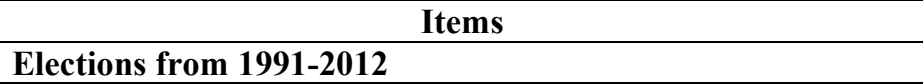 } & \multicolumn{2}{|c|}{ Rank } \\
\hline \multirow{11}{*}{ Performance } & & \multicolumn{2}{|c|}{ Ghana } \\
\hline & Ranked the effectiveness of EMB institutions & High & Medium \\
\hline & Electoral commission provide adequate facilities & Yes & Yes \\
\hline & Police performance in ensuring peace & Yes & No \\
\hline & Satisfaction with elections in connection with Voter Registration & Satisfied & Satisfied \\
\hline & $\begin{array}{l}\text { How effective are media and others institutions towards } \\
\text { election? }\end{array}$ & $\begin{array}{l}\text { Very } \\
\text { effective }\end{array}$ & effective \\
\hline & $\begin{array}{l}\text { There are effective and efficient performance of polling station } \\
\text { staff in all elections I have witnessed }\end{array}$ & effective & effective \\
\hline & $\begin{array}{l}\text { Could you tell me if you are very satisfied at the overall } \\
\text { situation in your country today because of elections? }\end{array}$ & satisfied & $\begin{array}{l}\text { Not } \\
\text { satisfied }\end{array}$ \\
\hline & Are elections fair & Fair & $\begin{array}{l}\text { Not too } \\
\text { fair }\end{array}$ \\
\hline & How would you rank the quality of elections in your country & Medium & low \\
\hline & Are you Satisfied with Democratic process in your country & Medium & Medium \\
\hline \multirow{5}{*}{ Independence } & $\begin{array}{l}\text { Ranked the rate of autonomy of the electoral commission in } \\
\text { your country }\end{array}$ & High & Medium \\
\hline & Does the electoral commission have a high capacity to function & Yes & No \\
\hline & $\begin{array}{l}\text { How satisfied are re you with elections in respect of } \\
\text { impartiality of polling station staff }\end{array}$ & Impartial & Impartial \\
\hline & Are you satisfied with the impartiality in tabulating results & $\begin{array}{l}\text { Not } \\
\text { satisfied }\end{array}$ & $\begin{array}{l}\text { Not } \\
\text { satisfied }\end{array}$ \\
\hline & Duty as neutral body guided in its work only by the law & High & Medium \\
\hline \multirow{8}{*}{ Credibility } & How free and fair is an election from 1991-2012? & Medium & Low \\
\hline & $\begin{array}{l}\text { Information on voting procedures and how to mark the ballots } \\
\text { was excellent }\end{array}$ & Medium & Low \\
\hline & Skills of the staffs of voting centres & Medium & Medium \\
\hline & High confidence in the Electoral Commission & Medium & Low \\
\hline & Much trust on the police? & Yes & Yes \\
\hline & Many people registered to vote in the most recent elections? & Yes & No \\
\hline & Do you trust the Electoral Commission & Medium & Low \\
\hline & How much do you trust the Media during elections & High & High \\
\hline \multirow{5}{*}{$\begin{array}{l}\text { Electoral } \\
\text { Violence }\end{array}$} & Have you witnessed violence in elections before & No & Yes \\
\hline & High rate of electoral violence & Low & Medium \\
\hline & $\begin{array}{l}\text { Observed electoral malpractices leading to violence in some } \\
\text { regions of the country }\end{array}$ & Low & High \\
\hline & EMB's do not perform well leading to electoral violence & No & Yes \\
\hline & $\begin{array}{l}\text { Have witness electoral violence throughout all elections in the } \\
\text { country }\end{array}$ & No & Yes \\
\hline
\end{tabular}

Table 3 shows the analysis on the ranked views of respondents on the relationship between electoral management bodies and the rate of electoral violence. The comparative analysis show that on the issue of performance both countries EMB have performed well throughout the elections from 1991 to 2012. However, Ghana performed better on all the indicators than that of Kenya. The results show that on the issue of "Ranked the effectiveness of each of EMB institutions and leaders in carrying out the duties that are their responsibility", majority of respondents in Ghana ranked its high as compared to majority of people in Kenya who ranked its medium. Moreover, on the issue of freeness and fairness of the national elections, majority of respondents in Ghana said fair while's majority of respondents in Kenya said not fair. In addition, on the issue of performance of the independent Electoral Commission in connection with its duty as neutral body guided by the law, majority of respondents in Ghana said high whiles that of Kenya, majority of respondents said medium. This analysis clearly shows that the EMB in Ghana functions effectively as compared to Kenyan counterpart. However, on some indicators the performance of both EMBs in Ghana and Kenya was the same depicting the great performance of work by the two EMBs. On the issue of effective and efficient performance of polling station staff in all elections, majority of the respondents in both countries said effective showing great performance by polling station staff in both countries.

Analysis was done on the independence of the EMBs in the performance of their duties. The results showed 
that there is high independence of the electoral commission in the performance of their duties for Ghana and Kenya except on the issue of "Ranked the rate of autonomy of the electoral commission in your country" which the results indicated that majority of respondents in Ghana said high whiles majority of respondents in Kenya said No. Moreover, on the issue of "Does the electoral commission have a high capacity to function" majority of respondents in Ghana have a yes opinion whiles majority of the respondents in Kenya gave no opinion. Besides the two issues, the results indicated a greater independence of electoral commission in both countries. Further the credibility of EMBs was also tested to help establish a clear relationship between the effective functioning of these institutions in managing the affairs of elections. The results from the ranked order show that on the issue of credibility Ghana EMBs have a higher credibility than that of Kenya is comparison. On the issue of "In your opinion, how free and fair general elections (Presidential and Parliamentary elections) from 1991-2012" majority of respondents in Ghana said Medium whiles majority of respondents in Kenya said low". This depict the low credible elections in Kenya as compared to that of Ghana.

In addition, rate of electoral violence was also tested. The results indicate that there is high rate of electoral violence in Kenya than in Ghana. On the issue of "Did you see or hear of any violence related to the Presidential or Parliamentary elections in your country” majority of respondents from Ghana said No, while's majority of respondents in Kenya said Yes. Further on that of "High rate of electoral violence", majority of respondents in Ghana said low whiles respondents from Kenya said medium. Moreover, on that of "EMB's do not perform well leading to electoral violence" majority of respondents said No in Ghana whiles majority of respondents in Kenya said Yes. In overall, it can be said that the higher performance, credibility, independence of EMBs has a greater relationship with the rate of electoral violence. The analysis shows significant relationship between the performance of EMBs and the rate of electoral violence. It indicates that there is a negative relationship between the performances of EMBs the rate of electoral violence. This means that the higher, the performance of EMBs, the lower the rate of electoral violence and the lower the performance in terms of independence and credibility the higher the rate of electoral violence. This is illustrated by the figure 3 below.

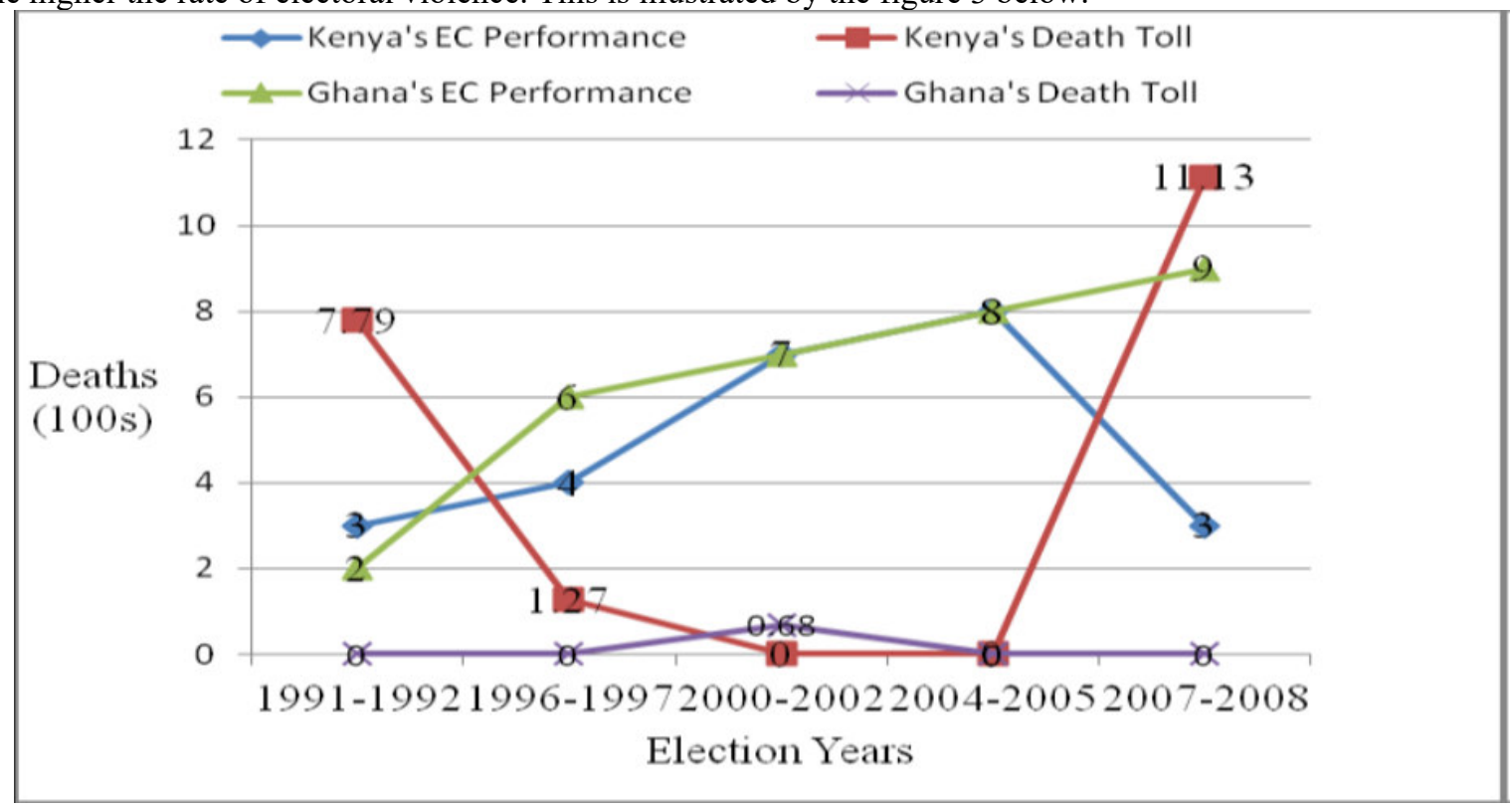

Figure 3: Election Deaths Compared with EMB Performance

Figure 3 illustrates the correlation between electoral performance of EMBs of Ghana and Kenya and the rate of electoral violence in two countries. It shows clearly that the performance of EMBs in the conduct of elections is inversely correlated to death toll registered as a result of electoral violence. It is evident from figure 3 that since the 1992 general elections, the performance of the Electoral Commission of Ghana shows a steady progress in the quality of electoral service. This has contributed immensely to the reduction of election related violence in Ghana. Though, some violence occurred at the early stages of the democratic process, it got diminished or eliminated overtime. The performance of the Electoral Commission of Kenya though shows a weak foundation, it nonetheless made progress in 2002 and 2005. Surprisingly, this progress performance was eroded in 2007 general elections. This could be attributed to the executive interference in the management of the electoral body of Kenya in the run-up to the 2007 presidential elections. Although the two countries share some commonalities in their political architecture, it is important to learn that Ghana's history of credible elections and the low rate of election-related violence could be attributed to the issue-based and non-ethnic nature of political campaigns. On the contrary, elections in Kenya have to a large extent been influenced by ethnicity, discriminatory distribution of national resources, fear, and lack of fairness in the justice distribution system 
(Nambiema 2012). This was epitomised in the 2007 general elections when the Kenya Electoral Commission suffered credibility deficit which contributed to its poor performance that eventually led to high incidence of electoral violence, deaths, displacement of people and loss of property.

The second hypothesis of the study tries to examine the relationship between the electoral system of both countries and electoral violence. The study analysed individual issues in relation the electoral system and the rate of electoral violence in both Ghana and Kenya. A comparative and contrasting analysis was conducted on the performance systems of EMB in both countries from 1991-2012. According to Nicholas Kerr (2009), diffuse support for institutions is critical for the acceptance of election results. He asserts that this diffuse support arises when citizens respect the role and function of the institution even when the institution delivers outcomes that diverge from their preferences. Therefore, institutional trust is fundamental to assessing the performance of EMBs and their output in determining whether elections are credible. The analysis assessed the EMBs' legitimacy. Thus, the legal status and the level of acceptance by the voters, and the extent of neutrality which is the absence of political control of the electoral process, and effectiveness of the EMBs service delivery per its mandate. Figure 4 shows the analysis on legitimacy of Electoral Commission of both Ghana and Kenya (19912012).

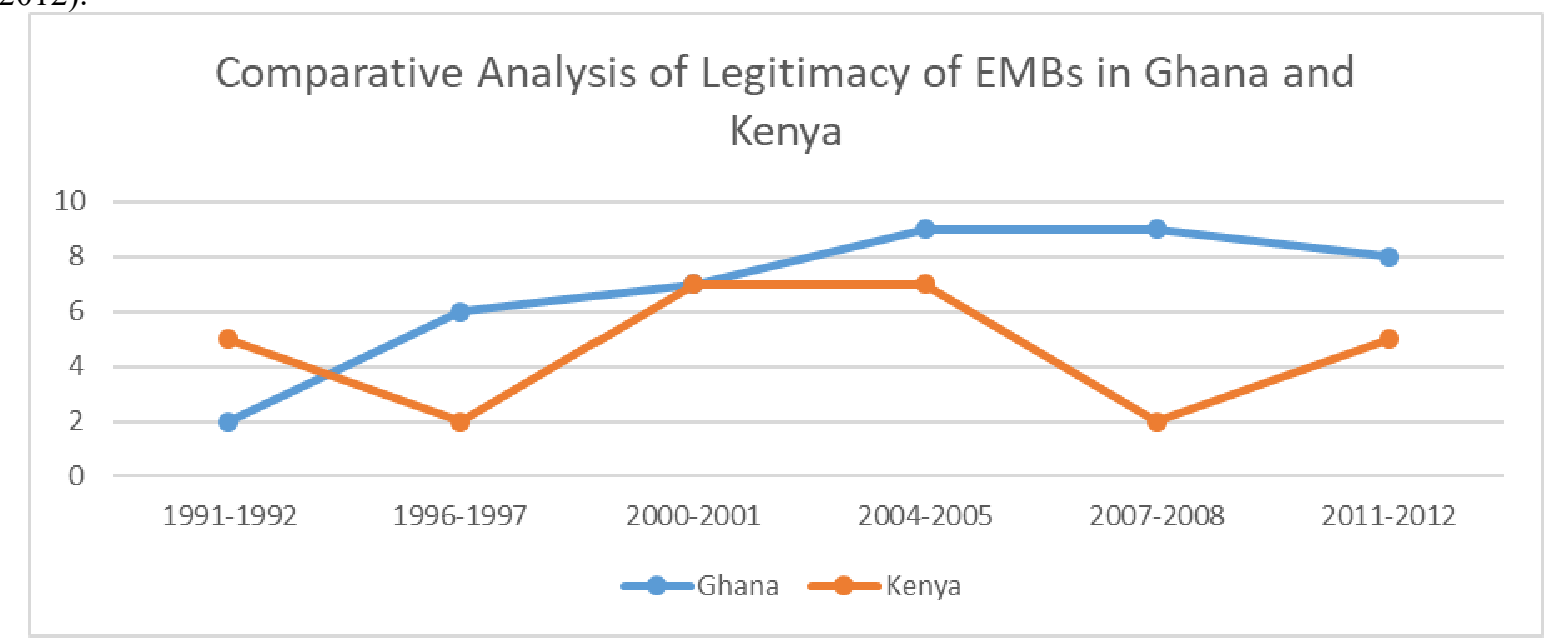

Figure 4: Comparative Analysis of Legitimacy of EMBs in Ghana and Kenya (2011-2012)

Figure 4 deals with the analysis on the legitimacy of the EMBs of Ghana and Kenya. The result shows that both EMBs made a poor start in the conduct of elections at the resumption of multiparty elections in 1991-1992. The EC of Ghana improved progressively over the years. In 2008, EC Ghana managed the delicate task of refereeing one of the most keenly and closely contested elections in the history of Ghana. The incumbent, NPP government, lost and handed over power to the opposition, NDC Party. On the other hand, the Electoral Commission of Kenya fluctuated in its performance and services delivery to the Kenyan electorate. It made progress after the 1997 elections, gained high legitimacy in 2002 elections and the 2005 referendum on constitutional reforms. The Commission however, flopped in the 2007 elections as the elections appeared rigged. President Kibaki's breach of constitutional arrangement in appointing the commissioners of the electoral body and the actions of the leaders EMB before, during and after election largely accounted for the low legitimacy rates of the Electoral Commission of Kenya in 2007. The legitimacy gap contributed to the perception that the elections may not be free and fair in Kenya. However, the 2011-2012 elections of both countries witnessed a massive improvement in their respective electoral system. 


\section{Comparative Analysis on Autonomy and Neutrality of Electoral Commission of Ghana and Kenya}

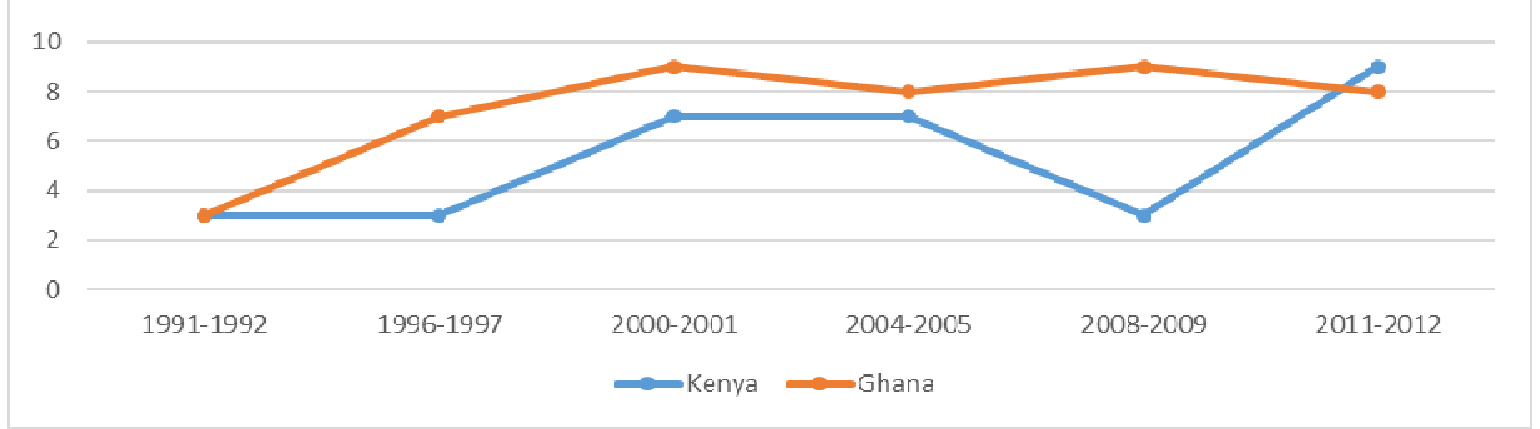

Figure 5: Comparative Analysis on Autonomy and Neutrality of Electoral Commission of Ghana and Kenya

Figure 5 demonstrates that the higher, the level of legitimacy, the higher, the level of perceived autonomy and neutrality which influence the level of acceptance of election results as credible. The results show that the autonomy and neutrality of EC Ghana shown a continuous rise from 1991-1992 to 2000-2001 with little fall in 2004-2005 and a higher rise in 2008-2009 and a steady fall in 2011-2012 elections. The steady fall in 2012 may be attributed to the election petition filed at the Supreme Court by the then opposition New Patriotic Party to challenge the validity of the 2012 election results. However, the trend of autonomy and neutrality in connection with EC Kenya shown a tremendous improvement from 1991-1992 general elections and little platooned in 2004-2005 and a drastic fall in 2008-2009 and a rise in 2011-2012. This shows much neutrality and autonomy of EC Ghana than EC Kenya throughout the elections conducted. Figure 6 shows the performance of both election management bodies.

\section{Comparative Analysis on Performance of Electoral Commission of Ghana and Kenya and Rate of Electoral Violence}

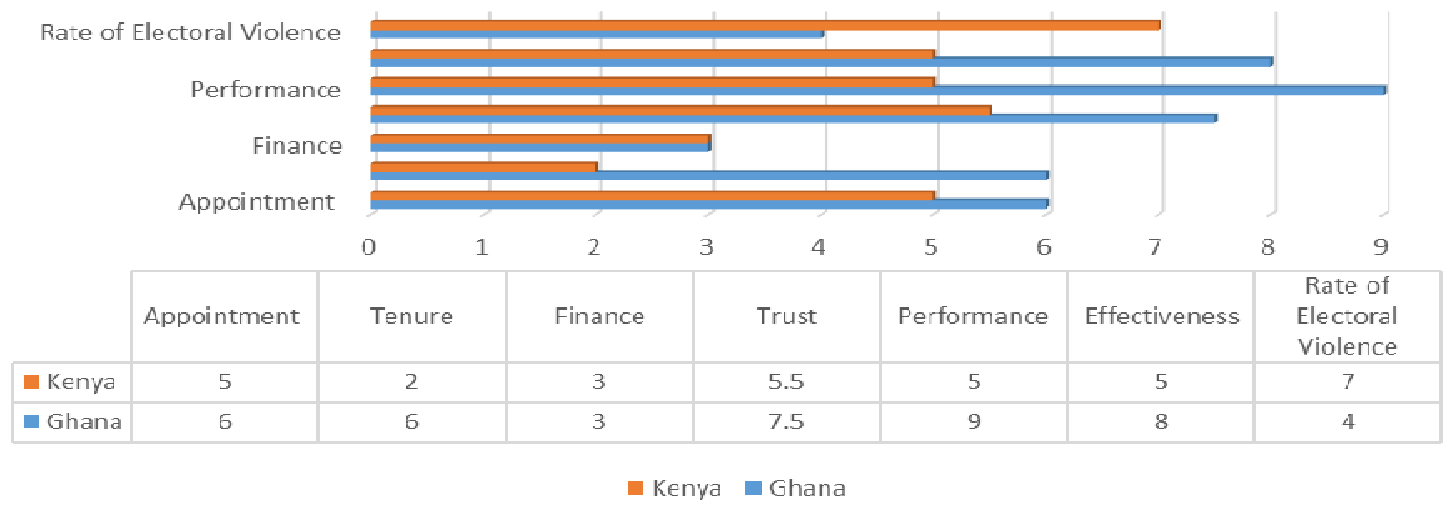

Figure 6: Analysis on Comparing the Performance of Electoral Commission of Ghana and Kenya (1991-2012).

Figure 6 shows data analysis on the issue of performance of EMBs in both countries on the issue of appointment, tenure, finance, trust, performance, effectiveness and rate of electoral violence. A close link to the issue of legitimacy are the questions of autonomy and the non-partisan nature of the ECs as well as the issue of performance. The results indicate that there is higher score for Ghana in five areas (except finance and rate of electoral violence) than Kenya. Ghana's EC demonstrated high capacity and during this period gained more of the confidence and trust of the electorate than the ECK had as indicated in the analysis. The analysis shows a high correlation between the quality of service provided by the election management bodies and level of autonomy, nonpartisanship, professionalism, rate of electoral violence of the two countries. 
Table 4. Effectiveness of Electoral System and rate of violence in Ghana and Kenya

\begin{tabular}{|c|c|c|c|c|}
\hline Statement on Electoral System and Violence & Gh: & & Ken & \\
\hline & Rank & $\%$ & Rank & $\%$ \\
\hline Electoral System: & & & & \\
\hline How effective is the electoral system in your country & High & $80 \%$ & Medium & $65 \%$ \\
\hline $\begin{array}{l}\text { How effective is the implementation of democratic process in your } \\
\text { country }\end{array}$ & $\begin{array}{l}\text { Very } \\
\text { High }\end{array}$ & $90 \%$ & High & $80 \%$ \\
\hline $\begin{array}{l}\text { How effective and efficient is the EMBs in ensuring a good democratic } \\
\text { process }\end{array}$ & high & $75 \%$ & Low & $30 \%$ \\
\hline Rate of Violence or Conflicts: & & & & \\
\hline $\begin{array}{l}\text { The effectiveness of the system has helped in reduction of electoral } \\
\text { violence and conflicts }\end{array}$ & Agree & $75 \%$ & Agree & $55 \%$ \\
\hline What is the rate of electoral violence in 1991-1992 elections & High & $75 \%$ & $\begin{array}{l}\text { Very } \\
\text { High }\end{array}$ & $90 \%$ \\
\hline What is the rate of electoral disputes in 1996-1997 elections & Medium & $60 \%$ & High & $80 \%$ \\
\hline What is the rate of electoral conflicts in 2000-2001 elections & Low & $20 \%$ & High & $80 \%$ \\
\hline What is the rate of electoral violence $2004-2005$ elections & Low & $30 \%$ & High & $75 \%$ \\
\hline What is the rate of electoral violence in $2007-2008$ elections & Very low & $10 \%$ & High & $80 \%$ \\
\hline What is the rate of electoral conflicts in $2011-2012$ elections & Medium & $45 \%$ & Medium & $50 \%$ \\
\hline
\end{tabular}

Table 4 shows data analysis on the effectiveness of electoral system and the rate of electoral violence in Ghana and Kenya. The analysis is in two part. The first part deals with the electoral system in both countries whiles the second part deals with the rate of violence in connection with the electoral system. The results show high effectiveness of electoral system in Ghana compared to Kenya. The Kenya electoral system is moderate in terms of effectiveness from the views of respondents. The results also indicate that the implementation, acceptance and effectiveness of democratic process and principles in Ghana is very high as compared to that of Kenya which is high. The role of EMBs in ensuring effective and efficient democratic system through the ballot is high in Ghana compared to Kenya which is low. The results again show that in both countries the effectiveness of the system has contributed to the reduction of electoral violence. In comparing the respondent's views on the rate of violence, the analysis indicates high rate of electoral violence in Kenya compared to Ghana which is low throughout all elections conducted in both countries. In critical analysis, it can be observed that ineffective implementation of an electoral system leads to high rate of electoral violence.

\subsection{Summary of Findings from the Test of Research Hypotheses}

Table 5 below indicates the test of research hypotheses which forms the basis of the findings of the study. Table 5. Test of Hypotheses

\begin{tabular}{|l|l|l|}
\hline Hypotheses & Statements & Explanation \\
\hline $\begin{array}{l}\text { Null Hypothesis } \\
1\end{array}$ & $\begin{array}{l}\text { There is no relationship between performance, independence, credibility of } \\
\text { election management body and the rate of electoral violence in Africa }\end{array}$ & Rejected \\
\hline $\begin{array}{l}\text { Alternate } \\
\text { Hypothesis 1 }\end{array}$ & $\begin{array}{l}\text { There is a relationship between election management body and the rate of } \\
\text { electoral violence in Africa. }\end{array}$ & Accepted \\
\hline $\begin{array}{l}\text { Null Hypothesis } \\
2\end{array}$ & $\begin{array}{l}\text { There is no relationship between electoral system and election-related } \\
\text { violence in Africa. }\end{array}$ & Rejected \\
\hline $\begin{array}{l}\text { Alternate } \\
\text { Hypothesis 2 }\end{array}$ & $\begin{array}{l}\text { There is a relationship between electoral systems and the rate of electoral } \\
\text { violence in Africa }\end{array}$ & Accepted \\
\hline
\end{tabular}

The results from table 5 indicate that all the two studies' hypotheses or alternated hypotheses found research support. This therefore explains that there is a relationship between performance, independence, credibility of election management bodies and the rate of electoral violence. Moreover, a relationship was also established between electoral system and the rate of electoral violence. All these findings establishing the relationships led to the rejection of all the null hypotheses in support of the studies' stated hypotheses.

\subsection{Conclusion}

The concept of democracy remains a puzzle despite countless attempts of academics and practitioners to find a common ground. Different definitions and theories emphasize different aspects of democracy. The study stipulated two research objectives and two hypotheses. The first hypothesis was tested on four main issues namely; performance, credibility, independence and rate of electoral violence. The findings show a significant relationship between the EMBs and the rate of electoral violence. It indicates that there is a negative relationship between the performances of EMBs the rate of electoral violence. This shows that the higher the performance of EMBs the lower the rate of electoral violence and the lower the performance in terms of independence and 
credibility the higher the rate of electoral violence. The second hypothesis stated that there is a relationship between electoral systems and the rate of electoral violence in Africa. The findings showed a significant correlation between electoral system and the rate of electoral violence. It was discovered that the ineffectiveness of EMBs in the implementation of an electoral system in line with the autonomy, legitimacy, and professionalism of the EMB leads to higher rate of electoral violence. This discovery indicates that the level of independence and non-partisanship execution of electoral administration is profoundly connected with the nature of electoral disputes and viciousness. This finding has established that there is a connection between the quality of election administration and the rate of electoral violence. In overall, the study's hypothesis was supported by the data analysis. It is recommended that to obtain democratic value through elections, African countries must develop an independent, autonomous, professional and effective election management bodies to neutralise the potential electoral and societal cleavages. This would enable election management bodies in Africa to conduct free, fair and credible elections that promotes peace and development on the continent.

\section{References}

Acemoglu, D, and Robinson, J. (2006). Economic Origins of Dictatorship and Democracy. New York: Cambridge University Press.

Africa Watch (1993). “Divide and Rule: State-Sponsored Ethnic Violence in Kenya,” New York: Human Rights Watch.

Afrobarometer (2006). Afrobarometer Round 2: Compendium of Comparative Results from a 15-Country Survey. Working Paper No. 34.

Agbaje, A., and Adejumobi, S. (2006). 'Do Votes Count? The Travails of Electoral Politics in Nigeria', Africa Development, XXXI (3), pp.25-44.

Ake, C. (1996). Democracy and development in Africa, The Brookings Institution, Washington.

Albert, I.O. (2006). "ECOWAS Parliament and Conflict Management in West Africa", The Nigerian Army Quarterly Journal (New series), Vol. 2 No. 2, pp. 174-196.

Alvarez, M.E, Cheibub, J.A, Limongi, F., Przeworski, A. (2000). Democracy and Development: Political Institutions and Well-being in the World, 1950-1990. New York: Cambridge University Press.

AMANI Forum (2008). Regional Parliamentarians Fact-finding Mission to Kenya on the Post-election Violence 13th-21st January 2008: Nairobi.

Asamoah, J.K (2019), "Electoral Management in Africa: A Facade or Reality-The Case of Election Dispute Resolution Mechanism", Journal of Public Policy and Administration, Vol.9, No.7, ISSN 2224-5731.

Bah, A. (2010). "Democracy and Civil War: Citizenship and Peacemaking in Côte d'Ivoire," African Affairs, vol.109, no. 437 , pp. 597-615.

Bassett, T 2011, 'Winning coalition, sore loser: Côte d'Ivoire's 2010 presidential elections', African Affairs, vol. 110, no. 440, pp. 469-479.

Bekoe, A. Dorina (2010). "Trends in Election Violence in Sub-Saharan Africa," United States Institute of Peace, Peace Brief, no. 13.

Berman, B., Eyoh, D., and Kymlicka, W. (2004). 'Ethnicity and the Politics of Democratic Nation-Building in Africa', Ethnicity and Democracy in Africa. Oxford: James Currey.

Birch, S. (2011). Electoral malpractice. Oxford University Press.

Birch, S. (2008). "Electoral Institutions and Popular Confidence in Electoral Processes: A Cross- National Analysis." Electoral Studies, vo.27, no.2, pp.305-321.

Brancati, D., and Snyder, J.L. (2011). "Rushing to the Polls: The Causes of Premature Post-Conflict Elections." Journal of Conflict Resolution.

Bratton, M., and van de Walle, N. (1998). Democratic Experiments in Africa: Regime Transitions in comparative perspective, Cambridge University Press, Cambridge.

British Broadcasting Corporation (2008). News on violent attacks when the candidate of All People's Congress (ACP).

Chacón, M., Robinson, J.A., and Torvik, R. (2011). When Is Democracy an Equilibrium? Theory and Evidence from Colombia's La Violencia. Journal of Conflict Resolution (Forthcoming).

Chan, P., and Chow, S. (2005). "Reliability and validity of the test of visual perceptual skills (non-motor), revised for Chinese pre-schoolers", American Journal of Occupational Therapy, Vol. 59, no.4, pp. 369-376.

Chazan, N. (1982). 'Ethnicity and Politics in Ghana'. Political Science Quarterly, vol.97, no.3.

Cohen, D. (1983). 'Election and Election Studies in Africa', Political Science in Africa: A Critical Review. London: Zed Books.

Collier, P. (2009). "Wars, Guns, and Votes: Democracy in Dangerous Places", New York.

Colomer, J.M. (2000). Strategic Transitions: Game Theory and Democratization, Johns Hopkins University Press.

Colomer, J.M., Banerjea, D., and De Mello, F.B. (2016). “To Democracy to Anocracy”, Center for Democracy 
and Civil Society, vol.13, Issue 1.

CIPEV (Commission of Inquiry into the Post- Election Violence) (2008). Final Report of the Commission of Inquiry into the Post- Election Violence. Nairobi: Government of Kenya and UNDP.

Creswell, J. (2001). “Research design: qualitative, quantitative, and mixed methods”, Thousand Oaks, CA: Sage. Dahl, R.A. (1989). Democracy and its Critics. New Haven: Yale University Press.

Dahl, R. A. (1971). Polyarchy: Participation and Opposition. New Haven: Yale University Press.

Dunning, T. (2011). "Fighting and voting: Violent conflict and electoral politics" Journal of Conflict Resolution, vol.55, pp.327-339.

Ekeh, P. (2004). 'Individual's Basic Security Needs and the Limits of Democratisation in Africa', Ethnicity and Democracy in Africa. Oxford: James Currey.

Elklit, Jørgen and Andrew Reynolds (2005a). "A Framework for the Systematic Study of Election Quality," Democratization, vol. 12, no. 2, pp.147-162.

Elklit, Jørgen and Svensson, Palle (1997). "What Makes Elections Free and Fair?” Journal of Democracy, vol. 8, no.3, pp. 32-46.

Feng, Y. (1997). Democracy, political stability and economic growth. British Journal of Political Science, vol.27, no.3, pp.391-418.

Fischer, Jeff (2002). "Electoral Conflict and Violence: A Strategy for Study and Prevention,” IFES White Papers, Washington DC: International Federation of Electoral Systems.

Foeken, D., and Dietz, T. (2000). 'Of Ethnicity, Manipulation, and Observation: The 1992 and 1997 Elections in Kenya', Election Observation and Democratization in Africa, Macmillan Press, pp. 122-49.

Fridy, K.S. (2007): The elephant, umbrella, and quarrelling cocks: Disaggregating partisanship in Ghana's fourth republic. African Affairs, 106 (2007) 423: 281-305

Ghana Statistical Service (GSS) (2019). "Ghana Living Standards Survey (GLSS) Report of Fifth Round (GLSS5),” [Online]. Available: http://www.statsghana.gov.gh.

Gurr, T. Robert (1993) Minorities at Risk: A Global View of Ethnopolitical Conflicts. Washington DC: United States Institute of Peace Press.

Harris, Peter. (1998). "Building an Electoral Administration”, Options for Negotiators, Stockholm: International IDEA, pp.308-319.

Hartlyn, J., McCoy, J., and Mustillo, T.M. (2008). "Electoral Governance Matters: Explaining the Quality of Elections in Contemporary Latin America." Comparative Political Studies, vol.41, no.1, pp.73-98.

Höglund, K., Jarstad, A.K., and Kovacs, M.S. (2009). 'The predicament of elections in war-torn societies', Democratization, vol.16, no.3, pp.530-557.

Hornsby, Charles and Throup, David. (1992). 'Elections and Political Change in Kenya.' The Journal of Commonwealth and Comparative Politics, Vol. 30, No. 2. pp. 172-99.

Horowitz, D. (1993). 'Democracy in Divided Societies', Journal of Democracy, vol.4, pp. 18-38.

Horowitz, D. (1991). "Electoral Systems for a Divided Society." In A Democratic South Africa? Constitutional Engineering in a Divided Society, University of California Press.

Huntington, S. (1991). "The third wave: Democratisation in the late twentieth century”, University of Oklahoma Press, Norman.

Hounkpe, M., Fall, I.M., Jinadu, A., Kambale, P. (2011). "Election Management Bodies in West Africa": A comparative study of the contribution of electoral commissions to the strengthening of democracy, Open Society Foundations.

Hyde, S.D. and Marinov, N. (2012). 'Which Elections can be Lost'? Political Analysis, Oxford University Press, vol.20. no.2, pp.191-210.

Ifeanyi, P. (2006). "Conflict resolution", a paper presented at the Institute of Medical Research and Training, Biode building College of Medicine, University College Hospital (UCH) Ibadan.

Jinadu, A.L. (1997). Matters Arising: African Elections and the Problem of Electoral Administration, African Journal of Political Science, vol.2, no.1, pp.1-11.

Kambudzi, A. (2008). 'Turning Elections into a Developmental Asset in Africa', Institute of Security Studies, Paper 163, June, Pretoria, South Africa.

Karl, T.L. (1990). "Dilemmas of Democratization in Latin America," Comparative Politics, vol.23, no.1, pp.1-21. Kenya National Bureau of Statistics (2019). "Kenyan Population and Economic Highlights," Nairobi.

Kerr, N. (2013). The Causes and Consequences of Electoral Administrative Reform In Africa, A Dissertation Submitted to Michigan State University in partial fulfillment of the requirements for the degree of Political Science-Doctor of Philosophy.

KHRC (Kenya Human Rights Commission) (2011). "Justice Delayed”: A Status Report on Historical Injustices in Kenya, Nairobi.

Leedy, P. D., and Ormrod, J. E. (2005). Practical research: Planning and design, Upper Saddle River, New Jersey: Prentice-Hall. 
Lehoucq, F, and J. Molina (2002). Stuffing the ballot box: fraud, electoral reform, and democratization in Costa Rica. Cambridge studies in comparative politics. New York: Cambridge University Press.

LeVan, C.A. (2011). "Power Sharing and Inclusive Politics in Africa's Uncertain Democracies," Governance, International Journal of Policy, Administration, and Institutions vol.24, n.1, pp.31-53.

Lewis, A. (1965). Politics in West Africa, London: George Allen and Unwin,

Lewis, P. (2007). Identity, Institutions and Democracy in Nigeria, Afro Barometer Working Paper No. 68.

Lindberg, I. Staffan (2009) Democratization by Elections: A New Mode of Transition. Baltimore, MD: Johns Hopkins University Press.

Lindberg, I. Staffan (2005). “Consequences of electoral systems in Africa: a preliminary inquiry." Electoral Studies vol.24, pp. 41-64.

Lindberg, I. Staffan (2006a). Democracy and Elections in Africa, Baltomore: John Hopkins University Press.

López-Pintor, R. (2010). Assessing Electoral Fraud in New Democracies: A Basic Conceptual Framework. Washington D.C. International Foundation for Electoral Systems: White Paper Series Electoral Fraud.

López-Pintor, R. (2000). "Election Management Bodies and Institutions of Governance," Bureau for Development Policy, United Nations Development Program.

Lund, C. (2003). "Bawku is Still Volatile:" Ethno-political Conflict and State Recognition in Northern Ghana," Journal of Modern African Studies, vol. 41, no. 4, pp.587-610.

Mansfield, E. and Snyder, J. (2007). Electing to Fight: Why Emerging Democracies Go to War, Cambridge, Massachusetts: MIT Press.

Mozaffar, S. (2002). "Patterns of Electoral Governance in Africa's Emerging Democracies," International Political Science Review, vol. 23, no. 1, pp. 85-101.

Mozaffar, S., and Schedler, A. (2002). "The Comparative Study of Electoral Governance: Introduction," International Political Science Review, vol. 23, no.1, pp.5- 27.

Mozaffar, S., Scarritt, J.R., and Galaich, G. (2003). Electoral institutions, ethnopolitical cleavages and party systems in Africa's emerging democracies. American Political Science Review, vol.97, pp.379-390.

Munck, G.L. (2009). Measuring democracy: A bridge between scholarship and politics. Baltimore: Johns Hopkins University Press.

Nambiema I.M. (2012). 'Counting Votes and Bodies,' Election-Related Conflict in Africa. Journal of African Elections, vol.7, New York: W. W. Norton \& Company.

Norris, P., and Mattes, R. (2003). "Does Ethnicity Determine Support for the Ruling Party"? Afrobarometer Working Paper 25.

Nugent, P. (2001). Winners, Losers and also Rans: Money, Moral Authority and Voting Patterns in the Ghana (2000) Election. African Affairs, vol.100, no.400, pp. 405-428.

Nyamu, H. (2003). Managing Elections in Kenya, in The Politics of Transition in Kenya: From Kanu To Narc, pp.265-272.

O'Donnell, G.A. (2001). Democracy, law, and comparative politics. Studies in Comparative International Development, vol.36, no.1, pp.7-36.

Omotola, J. Shola (2009). "Garrison' democracy in Nigeria: the 2007 general elections and the prospects of democratic consolidation", Commonwealth and Comparative Politics vol.47, no.2, pp.195-221.

Omotola, J. Shola (2008). "Explaining Electoral Violence in Africa's 'New' Democracies," (Paper presented at the 27 th Annual Conference of the Nigerian Political Science Association). Makurdi, Nigeria.

Omotola, J. Shola (2007). "Godfathers and the 2007 Nigerian general elections", Journal of African Elections, vol.6, no.2, pp. 134-154.

Pastor, Robert (1999). "The Role of Electoral Administration in Democratic Transitions: Implications for Policy and Research," Democratization, vol. 6, no. 4, pp. 28-89.

Polit, D., and Hungler, B. (2004) "Nursing Research, Principles and Methods" Philadelphia. Lippincourt, pp. 9192. Prentice Hall.

Posner, D. (2005) Institutions and ethnic politics in Africa. Cambridge: Cambridge University Press

Powell, G.B. (2004). The Chain of Responsiveness. Journal of Democracy, vol.15, no.4, pp.91-105.

Przeworski, Adams. (1991). Democracy and the Market: Politics and Economic Reforms in Europe and Latin America. New York: Cambridge University Press.

Reynolds, Andrew (2005). "Elections, Electoral Systems, and Conflict in Africa," Brown Journal of World Affairs, vol.16, no.1, pp.54-68.

Reynolds, Andrew (1999). "Electoral systems and democratisation in Southern Africa”, New York: Oxford University Press.

Saideman, S. and D. Lanoue (2005). “The (Exaggerated) Perils of Democracy: Analyzing Democracy's Influence on Different Forms of Communal Dissent," (paper presented at the Annual Meeting of the American Political Science Association). Washington, DC.

Schedler, A. (2006). Electoral authoritarianism. The dynamics of unfree competition. Boulder Lynne Rienner 
Publishers.

Schedler, A. (2002a). 'The Nested Game of Democratization by Election', International Political Science Review, vol.23, no.2, pp.103-122.

Schumpeter, J. A (1942). Capitalism, Socialism and Democracy, 2nd edition. New York: Harper Brothers.

Shane, McGee (2009). "Ethnic Divisions and Electoral System Design”: Prospects for Reform in Kenya IFES ISBN: 1-931459-31-2.

Shepard, R.J. (2002). Ethics in exercise science research. Sports Med, vol.32, no.3, pp.169-183.

Sue, N. (2001) "The Overview of Electoral Process" Regional Workshop on Capacity Building in Electoral Administration in Africa, African Training and Research Centre in Administration for development.

Sweeney Bill (2010). "Complaint Adjudications Standards: The seven steps to timely and effective dispute resolution”, Mundo Electoral, No.7, International Foundation of Electoral Systems.

Thomassen, Jacques (1994). 'The intellectual history of election studies.' European Journal of Political Research, vol.25, pp.239-245.

Tohbi, Vincent (2009). “Confidence Building Measures and Dispute Resolution”, Electoral Institute of

Southern Africa.

United States Institute for Peace (2010). "Trends in Electoral Violence in Sub-Saharan Africa”. Peace Brief, vol.13.

Van de Walle, N. (2003). "Presidentialism and Clientelism in Africa's Emerging party Systems. Journal of Modern African Studies, vol.41, no.2, pp.297-322.

Van Ham, C. (2009). "Beyond Electoralism? Electoral fraud in third wave regimes 1974-2009": Thesis submitted for assessment with a view to obtaining the degree of Doctor of Political and Social Sciences of the European University Institute.

Wall, A., Ellis, A., Ayoub, A., Dundas, C., Rukambe, J., Staino, S. (2006). Electoral Management Design: The International IDEA Handbook. Stockholm: Sweden: International Institute for Democracy and Electoral Assistance.

Weingast, Barry R. (1997). The Political Foundations of Democracy and the Rule of Law. American Political Science Review, Vol. 91, No. 2, pp.245-263.

Whitaker, B.E (2005). 'Citizens and foreigners: democratization and the politics of exclusion in Africa', African Studies Review, vol. 48, no.1, pp. 109-26.

Wilkinson, Steven I. (2004). Votes and Violence: Electoral Competition and Ethnic Riots in India. Cambridge: Cambridge University Press.

Wilkinson, Steven I. (2000). "Democratic Consolidation and Failure: Lessons from Bangladesh and Pakistan." Democratization, vo.7, no.3, pp.203-226.

Wolf, T., Carolyn, L., Jeremiah, O., and Kiage, P. (2004). "A New Dawn? Popular Optimism in Kenya After the Transition," Afrobarometer Working Papers, No. 33, Cape Town: IDASA, The Institute for Democracy in South Africa.

Zafiu, Teodora (2012) Master's Thesis Elections in Post-war Countries: A Way towards Peace and Democracy? 